\title{
Proceeding
}

7th INSHS International Christmas Sport Scientific Conference, 9-12 December 2012. International Network of Sport and Health

Science. Szombathely, Hungary

\section{Physical activities as a part of leisure in Czech society}

\author{
ALEŠ SEKOT \\ Faculty of Sport Studies, Masaryk University Brno, Czech Republic
}

\begin{abstract}
Sekot A. Physical activities as a part of leisure in Czech Society. J. Hum. Sport Exerc. Vol.8, No. Proc2, pp. S261-S270, 2013. Physical activity of people plays increasingly more important role in scientific interest regarding way of life of contemporary society and it is very important factor in the process of officiating of the level of healthy and active life style, quality of life and health in general. Indispensable role of physical activity in the course of human life is permanently scientifically confirmed also in context of prevention of obesity. The development of a sedentary life style is the result of a socialization process towards physical inactivity developed in youth and continued into adulthood. At the present we face in our cultural settings apparent tendency: People are more and more individualized, loosing beneficial impacts of community activities, involved in passive way of life lacking proper level of physical activities and active sport. Some preliminary data of the time of being in progress research of physical activity of Czech population are presented to describe specific relation of sport and sedentary society. The Czech Republic is on the level of mass sport strongly influenced with the existence of new development of the city structure, including fitness centres, cycle paths, roller skates stadiums, beach volleyball playing fields, golf courses. General conclusion of the paper is concentrated on the question what Czech society expects from sport in given context of existing tendencies in mutual relation of sport and society. Key words: PHYSICAL ACTIVITY, SPORT, OBESITY, SOCIETY, SOCIALIZATION, BUILT ENVIRONMENT, NUTRITION.
\end{abstract}

Corresponding author. Faculty of Sport Studies and the Faculty of Education at Masaryk University, Brno, Czech Republic. E-mail: sekot@fsps.muni.cz

7th INSHS International Christmas Sport Scientific Conference, 9-12 December 2012. International Network of Sport and Health Science. Szombathely, Hungary.

JOURNAL OF HUMAN SPORT \& EXERCISE ISSN 1988-5202

(c) Faculty of Education. University of Alicante

doi:10.4100/jhse.2012.8.Proc2.28 


\section{INTRODUCTION}

We are living a time when society, culture and science have become increasingly aware of the great importance of sport not only as a part of mass culture, but broadly understood, for individual and social health and well-being. The transformation from industrial to an information society since the1960st and fueled big advances in computer technology cause "the great wave of change". Significant changes in the composition of the workforce transferred the economic and the social roles of men and women, but also affected matters of health, attitudes to physical activities and sport (McElroy, 2002). As a result of political and economic changes, which occurred in the Czech Republic two decades ago, all areas of society started to be restructured. Naturally, this process also included public administration having responsibilities for many areas of the people's lives, including sport. This new way of "public matters provision" started at the beginning of the 1990s and culminated in the period of 2000-2002.

In general, the approaches of municipalities in the Czech Republic to sport show many differences. The causes of the identified differences and, in particular, of a totally different approach to policy making, therefore, must be sought elsewhere. In the different approaches to sport the political bias of elected and decision-making bodies of the municipality is reflected as well the degree of personal enthusiasm for sport of the persons who have decision-making authorities in the municipality. It is evident that in municipalities differing by their geographical position and appearance, the number of inhabitants and their socioeconomic characteristics and economic development: But the evident is: The sport policy making is not yet a common standard (Slepičková \& Staněk, 2007).

To summarize situation of sport versus local authorities in the Czech Republic the financial limitations and political priorities play very important role, as well as professional competence and personal preferences of particular councillors. The approach of the individual town areas to sport is very different and there are often original public policies in this field. A very diverse approach is also seen in the field of maintenance and development of the sports infrastructure and its utilization. In almost all of parts of the Czech Republic, the great importance is on renovation of school facilities. However, the access of the general public to the sport facilities often collides with the clearly commercial use of the facilities (Staněk \& Flemr, 2007).

\section{MATERIAL AND METHODS}

To discuss crucial topic "Physical activities in the Czech sociological perspective" means to present some relevant research data on physical and sportive activities of Czech population. At this context we also have to remind the fact, that the existing whirlwind of changes associated with way of life and standard of living regarding working activities, nutrition, housing, environment, transport, leisure, travelling etc. have with no doubt strong impact at a physically active lifestyle.

We live in the cultural setting adoring youth, beauty, healthy and sexy body and physical performance. Unfortunately, images of fit and healthy attractive personalities and widely circulated health messages have not translated effectively into increased physical activity for most Czech people. Findings from number of large- scale surveys point to the aversion or the inability of most Czech people to participate in regular amounts of physical activity. Sportive activities are more less rather the manifestation of "up to date" style of life, then as an integral part of everyday life. It is for more and more financially prospering people in good social position the expression of the prosperity and the ability to freely spend and choose independently their leisure. 
People prefer, in general, passive form of leisure, watching sport rather then doing sport. Overweight adults being deficient in good physical condition are putting themselves at risk for disease and disability. Medical expert predicted properly that the declines in physical activity the current generation of Czech children will grow into the most obese generation of adults in Czech history: The sedentary living beset contemporary Czech society, as identically U.S. and plenty of European societies too. In such situation we are more and more confronted with pressing questions: Why do people who know they should be more physically active still fail do so? What form the obstacles to achieving a more physically active lifestyle? And very pragmatic question is brought up to date: Is it in sedentary post-modern virtually oriented life possible to transform contemporary people into a more physical active society? What is the real prospect of our endeavour to create a social structure more conductive to a healthier society? Is it possible to overcome persistently questioned limitations found in many of the traditional approaches to promoting physical activity? Are we able to work effectively on the way of innovative strategy to increase physical activity at home, at school, and within the community (Sekot, 2008).

\section{RESULT}

Besides some partial surveys of leisure activities of young generation exists some representative researches of a position of sport and sportive activities of Czech population. One of the very representative with random sample of 952 respondents older 18 years of age organized Charles University in Prague. Research confirmed very high level of prestige of sport and sportive activities in Czech society (Slepička \& Slepičková, 2002). But at the same time was confirmed generally known fact that the significant part of population its positive attitude to physical activities does not realize in practical personal everyday life in the form of regular sport activities. Only one third of respondents declared regular sportive activity at least one time during a week, irregularly and by chance is involved in sport one fifth of respondents. Seventy percent of Czech people is not associated in sport organizations. On the decline is also positive opinion accenting an importance of mass sportive activity. Presented research has not been interested only in an opinion of Czech population on the role of sport for contemporary people, but was also searching for existing interests in alternative sports, prevailing barriers of active sporting, accessibility to sport facilities, level of passive and active interests regarding sport. Fundamental topic, general importance of sport and physical activities for Czech population is in mentioned research reflected in answer reflecting very high level of positive importance of sport for individuals and the society. The highest importance is connected with positive contribution of sportive activities for the health, fitness, well-being, social prestige. Such attitude reflects also high value acknowledgement and a credit of health for all generations of population. At the same time the impact of sport as an indispensable factor of socialization is growing, notably as a form of meaningful way of leisure. The results reflect also existing discrepancy between positive attitudes to sport and the conviction to be more intensively involved in active sport (Slepička \& Slepičková, 2002): Presented structure of attitudes to sport activities reflects given social and cultural situation in Czech post-reformation setting: People are not consistent enough to overcome their laziness, are to much busy, to much involved in everyday economic problems, not properly appreciated and enjoying refreshing impact of regular physical activities compensating many-sided stress of societal life. But we also take into account the fact, that people are prone to declare an absence of leisure as substitutional reason. Regarding future role of sport respondents declared prevailing widely sceptical opinions reflecting existing process of growing disparity between top elite professional sport and mass recreational sport. Such process also supports consumerist nature of contemporary sport in general. Most frequent reason for sportive activities of men is building up physical condition, body shape and societal prestige. Women are more sceptical in reference to their chance practise recreational sport regularly: They complain of absence of leisure, financial potentials and organisational obstacles. 
Relatively positive perception of physical condition of respondents is reflected in declaration of frequency of sport activities: One third of respondents declare active sport activities at lest once a week (37\% of men, $29 \%$ of women). Women are doing sport activities less regular in relation to men. Women are also more frequently absolutely physically inactive then men.

Presented data reflect in Czech population growing tendency of passive attitudes to sport. Physical inactivity is justified with absence of leisure, absence of meaningful motivation and an existence of healthy problems. $40 \%$ of "programmatic physically inactive "acknowledge substantial aversion to physical activity, $28,5 \%$ declare healthy problem and $20 \%$ absence of leisure. Only marginally is declared absence of sport facilities and financial obstacles (Slepička \& Slepičková, 2002).

Relevant recommendations regarding physical activities in Czech context are accenting the need to prepare and to realize self-contained programs for active recreational sport for all groups of population and within school teaching of physical education contribute to long-life interest in active physical activities (Frömel et al., 2006). In addition it is necessary to mention that 2 hours of physical education per week for pupils and students is not resolutely enough. Also young people are recommended for active participation in tourism, recreation and sport, as the foundation of physical culture. Physical education in its humanistic version is understood as "an education of man for the care of the body".

The research organized by Masaryk University, Brno "Physical activity in the perspective of physical activity of Czech inhabitants" being now in progress in the perspective of preliminary research data on sportive and physical activity in context of fundamental demographic indicators: sex, age, education, nature of occupation, domicile. Character of occupation of 1.117 respondents ( $505 \mathrm{men}, 612$ women) is as follows:

Table 1. Question no.1. Character of occupation/study

\begin{tabular}{cccccc} 
& Sex & Physical & Sedentary & $\begin{array}{c}\text { Physical and } \\
\text { sedentary }\end{array}$ & $\begin{array}{c}\text { No } \\
\text { work }\end{array}$ \\
\hline \multirow{2}{*}{ Sex } & Men & $13.66 \%$ & $41.39 \%$ & $33.47 \%$ & $11.49 \%$ \\
& Women & 9.16 & $35.78 \%$ & $33.82 \%$ & $21.24 \%$ \\
\hline \multirow{4}{*}{ Age } & $18-29$ & $11.59 \%$ & $39.02 \%$ & $38.11 \%$ & $11.28 \%$ \\
& $30-39$ & $12.64 \%$ & $45.98 \%$ & $34.10 \%$ & $7.28 \%$ \\
& $40-49$ & $10.36 \%$ & $45.60 \%$ & $41.45 \%$ & $2.59 \%$ \\
& $50-59$ & $12.93 \%$ & $42.86 \%$ & $38.10 \%$ & $6.12 \%$ \\
& $60-69$ & $7.03 \%$ & $18.75 \%$ & $18.75 \%$ & $55.47 \%$ \\
& $70-$ more & $10.00 \%$ & $8.33 \%$ & $3.33 \%$ & $78.33 \%$ \\
\hline \multirow{4}{*}{ Men } & $18-29$ & $15.34 \%$ & $36.81 \%$ & $38.04 \%$ & $9.82 \%$ \\
& $30-39$ & $13.68 \%$ & $53.85 \%$ & $31.62 \%$ & $0.85 \%$ \\
& $40-49$ & $15.73 \%$ & $42.70 \%$ & $38.20 \%$ & $3.37 \%$ \\
& $50-59$ & $11.48 \%$ & $50.82 \%$ & $37.70 \%$ & $0.00 \%$ \\
& $60-69$ & $9.62 \%$ & $28.85 \%$ & $25.00 \%$ & $36.54 \%$ \\
& $70-$ more & $8.70 \%$ & $8.70 \%$ & $0.00 \%$ & $82.61 \%$ \\
\hline
\end{tabular}




\begin{tabular}{|c|c|c|c|c|c|}
\hline \multirow{6}{*}{ Women } & $18-29$ & $7.88 \%$ & $41.21 \%$ & $38.18 \%$ & $12.73 \%$ \\
\hline & $30-39$ & $11.81 \%$ & $39.58 \%$ & $36.11 \%$ & $12.50 \%$ \\
\hline & $40-49$ & $5.77 \%$ & $48.08 \%$ & $44.23 \%$ & $1.92 \%$ \\
\hline & $50-59$ & $13.95 \%$ & $37.21 \%$ & $38.37 \%$ & $10.47 \%$ \\
\hline & $60-69$ & $5.26 \%$ & $11.84 \%$ & $14.47 \%$ & $68.42 \%$ \\
\hline & 70 - more & $10.81 \%$ & $8.11 \%$ & $5.41 \%$ & $75.68 \%$ \\
\hline \multicolumn{2}{|c|}{ Total } & $11.19 \%$ & $38.32 \%$ & $33.66 \%$ & $16.83 \%$ \\
\hline
\end{tabular}

It is evient that physical activity as an integral part of occupation is declining with sedentary character of professional work; there are not important differences between both sex groups: Sedentary occupations are more frequent in age group $50-59$ for men and $40-49$ for women.

Table 2. Question No. 2: Intensive physical activity during last seven days

\begin{tabular}{|c|c|c|c|c|c|c|}
\hline & & No activity & $\begin{array}{c}\text { Less than } \\
1 \text { hour }\end{array}$ & 1 - 3 hours & $3-6$ hours & $\begin{array}{c}\text { More than } \\
6 \text { hours }\end{array}$ \\
\hline \multirow{2}{*}{ Sex } & Men & $7.33 \%$ & $19.21 \%$ & $34.85 \%$ & $18.81 \%$ & $19.60 \%$ \\
\hline & Women & $9.64 \%$ & $28.27 \%$ & $35.46 \%$ & $14.87 \%$ & $11.44 \%$ \\
\hline \multirow{6}{*}{ Age } & $18-29$ & $6.10 \%$ & $21.95 \%$ & $35.37 \%$ & $17.99 \%$ & $18.60 \%$ \\
\hline & $30-39$ & $8.43 \%$ & $24.52 \%$ & $34.10 \%$ & $18.77 \%$ & $14.18 \%$ \\
\hline & $40-49$ & $9.33 \%$ & $20.73 \%$ & $40.93 \%$ & $16.58 \%$ & $12.44 \%$ \\
\hline & $50-59$ & $5.44 \%$ & $25.17 \%$ & $37.41 \%$ & $14.97 \%$ & $17.01 \%$ \\
\hline & $60-69$ & $14.06 \%$ & $31.25 \%$ & $28.91 \%$ & $12.50 \%$ & $13.28 \%$ \\
\hline & 70 - more & $16.67 \%$ & $28.33 \%$ & $28.33 \%$ & $13.33 \%$ & $8.33 \%$ \\
\hline \multirow{5}{*}{ Education } & No education & $0.00 \%$ & $0.00 \%$ & $0.00 \%$ & $100.00 \%$ & $0.00 \%$ \\
\hline & Elementary & $8.57 \%$ & $40.00 \%$ & $22.86 \%$ & $8.57 \%$ & $20.00 \%$ \\
\hline & Workmen & $14.17 \%$ & $19.17 \%$ & $32.50 \%$ & $15.83 \%$ & $17.50 \%$ \\
\hline & High school & $8.63 \%$ & $23.01 \%$ & $35.62 \%$ & $17.48 \%$ & $15.04 \%$ \\
\hline & University & $7.10 \%$ & $25.44 \%$ & $36.49 \%$ & $16.57 \%$ & $14.40 \%$ \\
\hline \multicolumn{2}{|c|}{ Total } & $8.52 \%$ & $24.22 \%$ & $35.25 \%$ & $16.68 \%$ & $15.16 \%$ \\
\hline
\end{tabular}

Men are more active in the field of physical activity than women, absence of physical activity during last seven days declare less than $10 \%$ of respondents, almost $20 \%$ of men are physicaly active more than six hours in last week. Absence of physical activity decline in the course of senior age, most physicaly active are youngest respondents. Workmen are most physicaly active; high school and university educated are in this respect comparable; physical inactivity is typical for elementary educated respondents. 
Table 3. Question No. 3: Regular daily walking in hours.

\begin{tabular}{|c|c|c|c|c|c|c|}
\hline & & No one & One hour & 1 - 3 hours & $3-6$ hours & $\begin{array}{c}\text { More than } \\
6 \text { hours }\end{array}$ \\
\hline \multirow{2}{*}{ Sex } & men & $1.19 \%$ & $28.91 \%$ & $36.83 \%$ & $23.56 \%$ & $9.50 \%$ \\
\hline & women & $0.65 \%$ & $18.14 \%$ & $41.83 \%$ & $24.84 \%$ & $14.38 \%$ \\
\hline \multirow{6}{*}{ Age } & $18-29$ & $0.30 \%$ & $19.82 \%$ & $42.99 \%$ & $24.70 \%$ & $12.20 \%$ \\
\hline & $30-39$ & $0.77 \%$ & $22.99 \%$ & $36.78 \%$ & $26.82 \%$ & $12.64 \%$ \\
\hline & $40-49$ & $1.55 \%$ & $25.39 \%$ & $39.90 \%$ & $22.80 \%$ & $10.36 \%$ \\
\hline & $50-59$ & $0.00 \%$ & $24.49 \%$ & $38.78 \%$ & $21.77 \%$ & $14.97 \%$ \\
\hline & $60-69$ & $1.56 \%$ & $21.88 \%$ & $35.16 \%$ & $28.13 \%$ & $13.28 \%$ \\
\hline & 70 - more & $3.33 \%$ & $31.67 \%$ & $43.33 \%$ & $13.33 \%$ & $6.67 \%$ \\
\hline \multirow{5}{*}{ education } & No education & $0.00 \%$ & $100.00 \%$ & $0.00 \%$ & $0.00 \%$ & $0.00 \%$ \\
\hline & Elementary & $2.86 \%$ & $25.71 \%$ & $31.43 \%$ & $22.86 \%$ & $17.14 \%$ \\
\hline & Workmen & $0.00 \%$ & $21.67 \%$ & $30.00 \%$ & $26.67 \%$ & $21.67 \%$ \\
\hline & High school & $1.55 \%$ & $21.68 \%$ & $40.04 \%$ & $23.67 \%$ & $13.05 \%$ \\
\hline & University & $0.39 \%$ & $24.06 \%$ & $42.21 \%$ & $24.46 \%$ & $8.88 \%$ \\
\hline & & $0.90 \%$ & $22.96 \%$ & $39.64 \%$ & $24.30 \%$ & $12.20 \%$ \\
\hline
\end{tabular}

Women are more active in walking than men; popularity of walking (as the most accessible way of natural physical activity) is growing with the course of the age. Almost $30 \%$ respondents of age group $60-69$ are daily walking 3-6 hours per day; low popularity of daily walking as reflection of sedentary professional way of life (and individual automobile transport to work too) is typical for age $40-49$. Walking is unpopular for young people and for respondents of lower educational status.

Particular data of presented research supported hypothesis on growing popularity of leisure physical activities of more educated people, high level of preference of walking in senior age groups and general tendency to sedentary occupations and professions.

\section{DISCUSSION}

To discuss broader problems of position of physical activities in sedentary society means also remind phenomenon of active style of life and responsible attitude to personal individual health and physical shape. Underlying health determinants of a socioeconomic nature play a major role in causing vulnerability to health risks, including obesity. Indeed, a social gradient in obesity has been demonstrated with individuals in lower socioeconomic groups (lower incomes or lower levels of education, or both) having a higher risk of being obese and thus of suffering from obesity-related diseases. The reasons why these inequalities have arisen and persist include the constraints imposed by low income and educational achievement on food choices, opportunities for recreational exercise, and differential absorption of health promotion messages.

People prefer, in general, passive form of leisure, watching sport rather then doing sport. Overweight adults being deficient in good physical condition are putting themselves at risk for disease and disability. 
Hlúbik et al. carried out an investigation on obesity in the Czech Republic in the year 2000. The study monitored 933 volunteers, both sexes and with an age ranges of 19-60 years. Anthropometric parameters such as weight, height, skin fold thickness and abdomen circumference were measured. BMI and fat tissue percentage were calculated on the basis of gathered data. The authors detected overweight in $67.5 \%$ of monitored men, obesity in $17.0 \%$ of them. $50.0 \%$ of women of were overweight while obesity was detected in $18.9 \%$ of them. Waist circumference exceeding $102 \mathrm{~cm}$ was measured in $41.2 \%$ of men and waist circumference exceeding $88 \mathrm{~cm}$ in $41.7 \%$ of monitored women. (Hlúbik, 2000).

Physical activity is a complex behaviour. Any activity can be described in terms such as intensity, frequency and duration, and these dimensions must be considered. An assessment methodology should also consider inactivity, such as time spent sitting. Physical activity can be related to work, transportation, home and leisure time. The activities at either of these domains may have specific health consequences, and advanced monitoring should also consider these. To present most important results of existing research data it is possible to conclude (Frömel et al., 2006):

1. Growing age of population (men and women too) decreases number of week days and volume of time devoted to physical activity.

2. Men in general are more involved in physical activities comparing with women.

3. Growing age decreases existing differences in intensity of physical activity between men and women.

4. Medium level of physical activity and walking is distributed in age groups and gender groups relatively evenly.

5. Walking is most frequent form of physical activity in Czech population.

6. Regular monitoring of level and tendencies of physical activity of population is integral part of monitoring of health situation and life style of population.

The phenomenon of obesity in the context of physical activity is strongly connected with the area of teaching of physical education on given level of school. One of the most important role for acquiring proper habits and patterns regarding regular lifelong physical sportive activity play primary and secondary schools. Research sample of $15311-15$ years old Czech rural pupils exposed $20.0 \%$ overweighted boys and $9.6 \%$ overweigted girl and $2.9 \%$ obese boys and $1.2 \%$ obese girls. Contrariwise $14.3 \%$ boys and $21.7 \%$ girls were under commensurate weight (Rýgl, 2006). Most respondents are interested in collective sportive activities (e.g. ski training, biking, boating). Most popular sportive game for 12 years old girls are ball game pig-in-the middle, rugby, floorball, volleyball and basketball. The same age boys prefer floorball, football, rugby, handball, and basketball. Overall results refer to high level of popularity of physical education comprehended mostly as an explicitly attractive activity. Research in such context accents a necessity to improve attractive and emotively experienced aspects of physical education to improve high competence of kinetic physical activities for lifelong body and healthy care. At that time the importance of strict "marking" of sportive performance is not recommended - more attention is concentrated for to support of individual ability to be regularly involved in physical/sportive activities. We believe that it is convenient step for to support popularity of regular all-round active leisure physical activities as an integral part of value orientation of young generation facing negative aspect of sedentary society.

\section{CONCLUSIONS}

What Czech society expects from sport?

Mutual relations of sport and society are mostly and visibly reflected in mediated television top sport events. In this context we face typical reflection of passive consumerism of sport as an important part of mass 
culture: people (society) expect from sport top performance, exciting show compensating monotonic course of everyday life. Society also found in top sport refreshing source of patriotism and medial celebrities, icons and heroes as a target of mass admiration in situation of their absence in the rest of society (mostly in politics). The existence of sedentary way of life detracts general level of physical/sported activities in everyday life of mass of people; growing importance of active way of life and human health improve phenomenon of individual responsibility for human wellbeing. People responsible for his or her physical and psychical good shape expect from sport an indispensable source of wellbeing, respect of their surroundings, and - the last and not least - his or her self-respect.

High level of political will and leadership are required to achieve a decrease in obesity prevalence. All relevant state sectors and levels should play a role in support of sport as a form of active way of life: the new horizons for civil society are here outlined. In mass society just the media have an important responsibility in propagation and dissemination of health life-styles.

To discuss a phenomenon of physical activity means in such perspective to accent changing nature of lifestyles and leisure time activities that have adopted new forms, contents and meanings. The world of sport and physical activities is also changing all the time in numerous new sport disciplines and activities which are be chosen by growing proportion of people. It could be expected that these changes would affect also the socialisation situations and environments of physical activity:

1. Presented structure of attitudes to sport activities reflects given social and cultural situation in Czech post-reformation setting: People are not consistent enough to overcome their laziness, are too much busy, too much involved in everyday economic problems, not properly appreciated and enjoying refreshing impact of regular physical activities compensating many-sided stress of societal life. But we also take into account the fact, that people are prone to declare an absence of leisure as substitutional reason. Relevant data reflects in Czech population growing tendency of passive attitudes to sport. Physical inactivity is justified with absence of leisure, absence of meaningful motivation and an existence of healthy problems. $40 \%$ of "programmatic physically inactive" acknowledge substantial aversion to physical activity, $28.5 \%$ declare healthy problem and $20 \%$ an absence of leisure. Only marginally is declared absence of sport facilities and financial obstacles (Slepička \& Slepičková 2002).

2. To present most important results and informations on tendencies in he field of physical activities means to conclude that growing age of population (men and women too) decreases number of week days and volume of time devoted to physical activity. Men in general are more involved in physical activities and active transport (cycling, walking) comparing with women.

3. Nowadays physical education is defined as the process aiming at preparation of children and young people for participation in physical culture (tourism, recreation, sport). It is also understood as the foundation of physical culture. Physical education in its humanistic version is understood as "an education of man for the care of the body preparing children and young people for taking responsibility for health, fitness and the beauty of the body after competing education.

4. Phenomenon of physical/sportive activity is many-sided phenomenon connected with the concept of a healthy life style. Life style behaviours in general are significantly determined by social status, by professional position, by amounts of money and the quantity of property. Those who have the means may choose to be physically active; those lacking the financial resources cannot freely to choose to be 
involved in regular sportive activities. Unhealthy behaviours, including sedentary lifestyles, are influenced by people's position within social groups and broad social forces in the general society.

5. Recommendations to sport organizations for the systematic pomotion of physical activities needs full support of local, regional and national public authorities:

1. To develop a membership strategy to include physically passive persons to sportive activities.

2. To specify the profile target of sport clubs with accordance to focus on elite and competitive sport or recreational leisure sport activities.

3. To improve coach and trainer standards of an inclusive social and pedagogical climate.

4. To accent natural outdoor activities as grass roots centres for mass involvement in physical activities.

5. To ensure and to enable high educational and pedagogical standards of voluntary and (semi) professional staff in sport clubs.

We can conclude: Healthy lifestyles are patterns of voluntary behaviours based on choices from options that are available to people according to their life situations. In developed post industrial countries the members of upper and middle class by way of active lifestyle mostly reflect their value self identity accenting balanced share of an intellectual and a physical activities. It is a tendency to evaluate good health as a personal value to be sought and cultivated for one's own benefit, such as experiencing increased vitality and enjoyment of life. Lower-class individuals, with reference to the nature of their work activities and income, are less optimistic to ovoid poor health and thus are less apt to participate in systematic health promoting activity. Anyway, people in lower socioeconomic position experience poorer health and higher disease rates when compared with more privileged social groups.

6. Phenomenon of physical activity and sport is closely related to urbanisation of sports facilities. In such context it is useful to describe and analyse the most important milestones in the history of city-planning (urbanisation) in the area of sport facilities. The rapid housing and industrial development is resulting in numerous urban-architectural and moreover sociological issues. Sport facilities planning, creating, developing and managing should be considered to be one of the strategic points in public (administration) on both the local and state level (Flemr, 2007).

Even the preliminary results of presented research data and pilot studies imply that the individual municipal authorities in the pertinent town areas attach a diametrically different importance to sport and sporting activities. A large difference is already visible in the managing of sport and sporting activities within the organizational structures of the municipal authority. The most critical policy area on physical/sportive activity is the sole fact of sedentary nature of contemporary society: Very high level of prestige of sport and sportive activities in Czech society is incompatible with very low level of practical regular physical or sport activities.

\section{REFERENCES}

1. FORMÁNKOVÁ, S. Některé oblasti longitudinálního výzkumu zájmu žáků o pohybovou aktivitu. Celostátnívědecká konference $s$ mezinárodní úèastí v oborukinantropologie. Olomouc: Hanex. 1998.

2. FLEMR, L. Urbanismus sportovních zařizení. Česká kinantropologie. 2007; 1: 93-105.

3. FOŘT P. Stop dětské obezitě. Praha: Ikar. 2004. 
4. FRÖMEL K, ET AL. Physical activity of men and women 18 to 55 years of age in Czech Republic. In. F. Vaverka (ed). Movement and Health. Olomouc: Univerzita Palackého. 2004:169-173.

5. FRÖMEL K, BAUMAN A, ET AL. Intenzita a objem pohybové aktivity 15-69 leté populace České republiky. Česká Kinantropologie. 2006; 10(1): 13-27.

6. HLÚBIK P, ET AL. Prevalence of obesity in selected subpopulations in the Czech Republic. Sborník Lékařský. 2000; 1: 59-65.

7. MCELROY M. A Social Analysis of Inactivity. Champaign, IL: Human Kinetics. 2002.

8. Project no. 044291 Prevention of Obesity in Europe - Consortium of the prevention of obesity through effective nutrition and physical activity actions - EURO-PREVOB.

9. RYCHTECKÝ A. Active lifestyles of young people - benefits and outcomes. Obesity in Europe. Young people's physical activity and sedentary lifestyles. Berlin, Oxford: Peter Lang. 2007: 199218.

10. RÝGL P. Tvorba školních vzdělávacích programů pro oblast tělesné výchovy na základní škole. Česká Kinantropologie. 2006; 10(2): 29-45.

11. ŘíHOVÁ M, SKÁLOVÁ L, KOMÁREK L. Health behaviour of young people. School and Health 21. Brno: Masarykova univerzita a Paido. 2007:125-139.

12. RZEWNICKY R. Health enhancing physical activity. Measurement and determinant of daily activity at home, work, travel, and leisure. Leuven: KU Leuven. 2003.

13. SEKOT A. Sociologie sportu. Brno: Masarykova univerzita a Paido. 2006.

14. SEKOT A. Physical activity versus obesity. Educatio Artis Gymnasticale. 2008; 3(3): 51-72.

15. SEKOT A, BRÁZDOVÁ Z. Physical activity and nutrition as a social factors influencing the epidemic of obesity. Studia Sportiva. 2008; 2(1): 112-125.

16. SEKOT A. Determinanty nadváhy a obezity: Pohybová aktivita a materiální prostředí. Zdraví. 2010. 1: 24-32.

17. SLEPIČKA P, SLEPIČKOVÁ I. Sport z pohledu české společnosti. Česká Kinantropologie. 2002; 1: 7-23.

18. SLEPIČKOVÁ I, STANĚK M. The impact of public administration reform on sport policy in Czech Republic. Local Sport in Europe. EASS 4th Conference Proceedings. 2007.

19. STANĚK M, FLEMR L. The role of local authorities of Czech cities in support of sport: A case study of the capital city of Prague. Local Sport in Europe. EASS 4th Proceedings. 2007. 